\title{
Socioeconomic status and health shocks; analysis of coping strategies in rural households of Enugu State, Nigeria
}

\author{
Chinasa E. Urama1, Yemi Adewoyin², Ezebuilo R. Ukwueze ${ }^{1}$ \\ \& Jecinta C. Ene ${ }^{3}$ \\ ${ }^{1}$ Department of Economics, University of Nigeria, Nsukka, Nigeria \\ ${ }^{2}$ Department of Geography, University of Nigeria, Nsukka, Nigeria \\ ${ }^{3}$ Department of Social Work, University of Nigeria, Nsukka \\ Email: yemiadewoyin@yahoo.com
}

\begin{abstract}
Background: Health burden in rural areas of developing countries is worsened by the limited coverage of health insurance. With constrained access to quality healthcare and constituting two thirds of Nigeria's poor, this study investigates how rural households cope with health shocks consequent on their socioeconomic status.

Method: Data was collected from 600 households in Enugu using a questionnaire. Cross-tabulation, chi square and multiple regression statistical techniques were employed for data analysis.

Findings: About $53 \%$ of the respondents were male household-heads while borrowing $(47.65 \%)$, sales of assets $(43.85 \%)$, diversion of funds $(2.00 \%)$ and reduced expenditure $(6.48 \%)$ were the main coping strategies. Education, occupation, and income statistically influenced the coping strategies $(P<0.005)$ and jointly accounted for $26.5 \%(R 2=0.265, P<0.001)$ of the variations in coping strategies.

Conclusion: Having a rural healthcare policy and mainstreaming the informal sector into the national health insurance scheme will ameliorate health shocks among the rural poor.
\end{abstract}

Keywords: Health Shocks, Coping Strategies, Socioeconomic Status, Rural Households, Healthcare Expenditure, Enugu State, Nigeria

\section{Introduction}

Healthcare delivery in Nigeria is poor and worsening with the increase in the population of the country's poor. According to a World Health Organization (WHO) report, Nigeria is placed 187th among 200 countries on the global healthcare delivery system ranking (Ephraim-Emmanuel et al, 2018). The situation stems, not only from the inequality in the distribution of healthcare facilities between urban and rural areas, among residential neighbourhoods within the urban areas, and from physical accessibility to the facilities (Adewoyin et al, 20l8; Akpomuvie, 20l0), but also from affordability and quality of care; both of which are dependent on household income and socioeconomic status. This follows from the fact that in most developing countries, Nigeria inclusive, the bulk of health care expenditures is financed through out of pocket payments made at the point of use (Quintussi et al, 20I5; WHO, 20I0). Such payments cover direct costs for hospital registration cards, doctor's consultation fees, laboratory tests and drugs, as well as indirect costs like transportation and loss of man-hour for the patients and their care-givers or family members. As Onwujekwe et al (2010) observed, out of pocket payment is the major strategy for healthcare payment in Nigeria owing http://aps.journals.ac.za largely to the absence of intermediation and insurance mechanisms to manage health risks. According to a World Bank data, households' out of pocket expenditure for health in Nigeria constituted $72 \%$ of total health expenditure and $95 \%$ of private health expenditure in 2015 (World Bank, 2016).

Nigeria runs a national health insurance scheme that caters for only federal public servants. This category of workers constitutes less than $1 \%$ of the total population and resides mostly in urban Nigeria. The scheme does not provide cover for people employed in the informal sector. It is from the sector that the bulk of the population makes a living, especially the rural population. The situation in the rural areas is worse off. Not only do these areas house about two thirds of the country's poor who engage in informal employments, they also lack most basic social amenities, including quality healthcare facilities. As such, the population has a livelihood that is dependent on primary activities, suffers a constrained access to healthcare, and has poorer health outcomes. Studies have shown that heavy spending on healthcare, especially by rural households of developing countries, impacts negatively on the economy of such households; leads 
about 100 million households deeper into poverty annually, and prevents many poor households from seeking adequate healthcare (Higgins-Steele et al, 2015; Vesel et al, 2015; World Bank, 20I4; Akazili, 2010; Falkingham et al, 2008; Xu et al, 2003). The growth of healthcare expenditures is of particular concern to rural households whose incomes are significantly lower than their urban counterparts (Lee et al, 20I4), especially as these households have little income or wealth to buffer against the negative impacts of adverse health events (Leonard et al, 2017). Coping with these adverse effects in the face of poor income and catastrophic out of pocket expenditure in the rural areas thus becomes a concern.

In this study, an attempt is made to understand the various mechanisms adopted by the rural households in Enugu State, Nigeria in coping with adverse health events that have implications for their income. These events, otherwise referred to in this study as health shocks, trigger a decline in well-being and are associated with illnesses and fatalities. Clarke and Dercon (2009), following Dercon et al (2005), define shocks as adverse events that are costly to individuals and households in terms of lost income, reduced consumption or the sale of assets. The study becomes important against the background that there is a bias against rural areas in the distribution of healthcare facilities (Almeida et al, 2017; Akpomuvie, 2010); a bias that is implicated in the poor health outcomes in the rural areas (Bonfrer and Emily Gustafsson-Wright, 2017; Lee et al, 2014). The rural population also earns less than their urban counterparts, is not covered in the national health insurance, and has to pay a significant proportion of that income as out of pocket expenditure on healthcare. This interrelationship has the capacity to reinforce poverty in the rural areas at a time the continent is striving to promote inclusive growth and sustainable development through the African Union Agenda 2063. The socioeconomic determinants of the coping mechanisms are also investigated. An analysis of the socioeconomic characteristics influencing household choice of coping measures is necessary for policy formulation to address health shocks and poverty linkage in the rural areas.

\section{Literature review}

Shocks can be decomposed into different categories depending on their nature of origin; climatic, economic, political, crime, and health shocks (Pradhan and Mukherjee, 2016). Climatic shocks comprise drought and flood, erosion, frosts and pestilence affecting crops or livestock etc. Economic shocks include problems in terms of access to inputs, decreases in output prices and difficulties in selling agricultural and nonagricultural products. Crime shocks take account of theft and/or armed robbery, destruction of crops, livestock, housing, tools or household durables as well as crimes against persons. According to Pradhan and Mukherjee (20I6), health shocks include both death and illness. Depending on the scope, this broad categorization can be grouped into idiosyncratic and covariate shocks (UNDP, 20I I; Clarke and Dercon, 2009; Dercon, 2002). Idiosyncratic shocks affect individuals or households while covariant shocks affect groups of household, communities, regions or even entire countries. Idiosyncratic shocks include illness and death of a household member, and covariate shocks which affects a group of people residing in a particular area at the same time (Dercon, 2002). These shocks can lead to pain, despondency, and loss of income and assets.

Studies have shown that household's ability to cope with shocks is dependent on the type of shock and household characteristics. In many developing countries, coping measures became very vital to poor rural households because they lack formal protection against financial risk (Bonfrer and Gustafsson-Wright, 2017; European Report on Development, 2010), have limited resources and are mostly exposed to shocks (Abegunde and Stanciole, 2008). Strategies to cope with illness shocks can be financial and nonfinancial. Financial strategies can be in the form of dependence on informal transfers, the use of assets and borrowing while non-financial strategies include alterations in labour supply, diversification of income sources and changes in household structure (Rugalema, 2000; Beegle et al., 2008). Selling of assets to maintain consumption, offset illness costs and other pressing needs has been long recognized as a shock coping strategy (Sauerborn et al. 1996; Wilkies et al., 1997; Kazianga and Udry, 2004; McPeak, 2004; Hoddinott, 2006; Goudge et al., 2009). The unwelcomed effect of shock has been found to have a greater impact on the rural poor households than on the richer households as these households, most often, adjust their consumption levels to cope with the shocks (Russell, 2005; Jalan and Ravallion, 1999).

Households can cope with consumption and other household needs by accessing assets and wealth accumulated during ordinary period (Dercon and Krishan 2000). These poor rural households are mostly engaged in agriculture with low productivity and low income (Tirivayi, Knowles and Davis, 20/3), and drawing on these accumulated wealth is near impossible. Several coping measures have been found to benefit these households, especially informal household transfers particularly when the shock is idiosyncratic (Linnemayr, 2010) but can become less 
beneficial when the shock is permanent. Other studies found hired labour or labour reciprocity as common strategies adopted to cope with consumption but more recent study by Sparrow et al. (2014) found borrowing as the major strategy to cope with illness costs. A study by Bonfrer and Gustafsson-Wright (2017) also found previous savings followed by selling of livestock, land and other assets, and not doing anything in the presence of health shocks as the initial coping measures adopted by households. Leive and Xu (2008) found borrowing as the initial coping strategy in a study of 15 African countries. In a Cambodian study, Kenjiro (2005) found that health shocks occur more frequently and cause more damage to households than crop failure.

Some studies on coping strategies have dwelt on the effect of social networks in coping with illness costs. Sauerborn et al (1996) found an insignificant role of social network in mitigating the effect of shocks on poor rural households while Wilkies et al. (1997), Russell (2004), and Russell and Gilson (2006) found the contribution to be significant. Rahman et al (2013) found an inverse relationship between 'distress financing' and household assets. The study suggests that the probability for rural household in Bangladesh to experience 'distress financing' increased as the assets of household decreased. As noted by Nguyen et al (2012) however, over reliance on household income to offset health payments compounds the problems of household instead of providing health security. Studies have shown that since poor rural households in many developing countries are not able to provide health insurance for their members but can only partly smooth consumption when the shock is not frequent (Asfaw and Braun, 2004; Islam and Maitra, 20I2; Nguyen and Mangyo, 2010), financial assistance from friends and relatives, loans and disposal of assets become unavoidable coping strategies (Tahsina et al., 2018).

Although coping mechanisms have been found to be very helpful to households, the end result can be enormous (Flores, Krishnakumar, O'Donnell, and var Doorslaer, 2008). Formal and informal borrowing, movement of labour resources of the household and other forms of assistance employed by households to cope with illness shock have implications for household poverty (Tongruksawattana and Schmidt, 2010). Assets depleted can trigger a vicious cycle of poverty and borrowing can also keep households in debt for a long time (Damme et al, 2004). Donations received from households of relatives and friends can also have a significant negative effect on the donor household in terms of forfeited profit that would have been obtained from foregone investment (Grimm, Hartwig, and Lay, 20I I). Some households also had to forgo necessary health treatment as a coping option (Grimm, 20I0). In general, poor rural households are mostly exposed to harsh coping measures which lead to poor health outcomes and have the tendency of throwing the household deeper into poverty. While much is known about health shocks coping strategies globally, how this plays out in rural Nigeria is yet to be investigated. Further, not much is known about how socioeconomic characteristics of households influence the choice of coping strategies they make. This study is an endeavour at investigating these.

\section{Data and methods}

\section{Population and sample}

The research was conducted in the three senatorial zones of Enugu State, Nigeria. Enugu was purposively selected for this study because of the authors' relative familiarity with the socio-cultural and economic structures of the State. This was to facilitate the ease of data collection and enhance a robust interaction with the respondents who have a similar background and speak the same dialects with the researchers. Enugu had an estimated population of 3,257,298 based on the 2006 NPC census figures with Enugu North having I,229,8 I I people, Enugu West having 87I,I62 people and I,I66,864 people residing in Enugu East senatorial district. The State covers an approximately 12,727 square kilometers, lies partly within the tropical rain forest belt to the south, and is located in the South-East geo-political zone of Nigeria. The native population is entirely Igbo. The State is noted for its coal deposit, the largest in Africa and majority of the population is engaged in farming. Furthermore, the State is characterized by heavy disease burden and heavy out-of-pocket financing as is the case in most States in Nigeria. The State is also dominated by small-sized private for-profit health facilities.

The target population for this study was the number of households in the rural communities of Enugu State. According to Ugwu, (2009), about 59\% of Enugu State population lives in the rural areas. With an estimated total population of $3,257,298$, the rural population is computed to be $1,921,806$ people. And as there is an average of five persons per households in rural Nigeria according to the Nigerian national bureau of statistics, this figure is further decomposed to $384,36 \mathrm{I}$ households. Following Cohen et al (2007) and using a confidence level of $95 \%$ and a confidence interval of $\pm 3 \%$, a total of 600 households were selected for the study. Using a multi-stage sampling technique, one Local Government Area (LGA) was randomly selected from each of the three senatorial districts while three rural communities were further selected from each of the three LGAs. Obukpa, Nru and Obimo communities were selected from Nsukka 
L.G.A, Amaechi-Idodo, Ozalla, and Nomeh communities were selected from Nkanu West L.G.A while Udi, Amagunze, and Nenwe communities were selected from Udi L.G.A. The 600 sampled households were randomly selected from the nine communities.

\section{Data collection and analysis}

The study employed a cross-sectional survey research design using self-reported information. Primary data was collected, between March and May 2018, from household heads or, in their absence, their spouses in the selected households using a structured questionnaire. The questionnaire was designed in an interviewer-administered format such that each item on the questionnaire question was elaborately explained to the respondents in a language they understood and their responses were captured accordingly. The reliability of the research instrument had earlier been ascertained using the test-retest method. Items captured in the construct included demographic and socioeconomic characteristics like age, gender, level of education, occupation and income. Other items included questions on the prevalence of diseases, ill-health and associated fatalities over which the households had to spend money, and strategies for coping with the identified health shocks. The data sets were coded appropriately and analyzed using frequency, simple percentages, cross-tabulation, chi square and multiple regression statistical techniques. Overall, only 509 of the 600 questionnaire copies were valid for the analysis.

\section{Results}

Demographic and socioeconomic characteristics

About $53 \%$ of the respondents were male while female respondents were $46.8 \%$. More than $97 \%$ of the respondents were household heads. Spouses of household heads constituted $2.9 \%$ of the respondents. This suggests that, in the study area, there is almost a gender balance in the distribution of household heads between male and female. From the analysis of the 509 valid copies of the questionnaire, respondents from Enugu North were 216 (42.4\%) while there were $186(36.5 \%)$ and 107 (21.0\%) respondents from Enugu East and West senatorial districts respectively. The occupational distribution of the respondents indicates that $71.9 \%$ of them were engaged in farming while two respondents were nursing aids. Other occupations identified from the survey were trading, hair dressing, mechanic, tailoring, teaching, and clerical works. The occupational distribution is illustrated in Figure I. Almost $41 \%$ of the respondents had no formal education, $35.7 \%$ was not educated beyond primary school, $16.1 \%$ attended a secondary school, $2.4 \%$ had university education while $5.1 \%$ attained other forms of educational level such as teacher training certificate and other academic diploma.

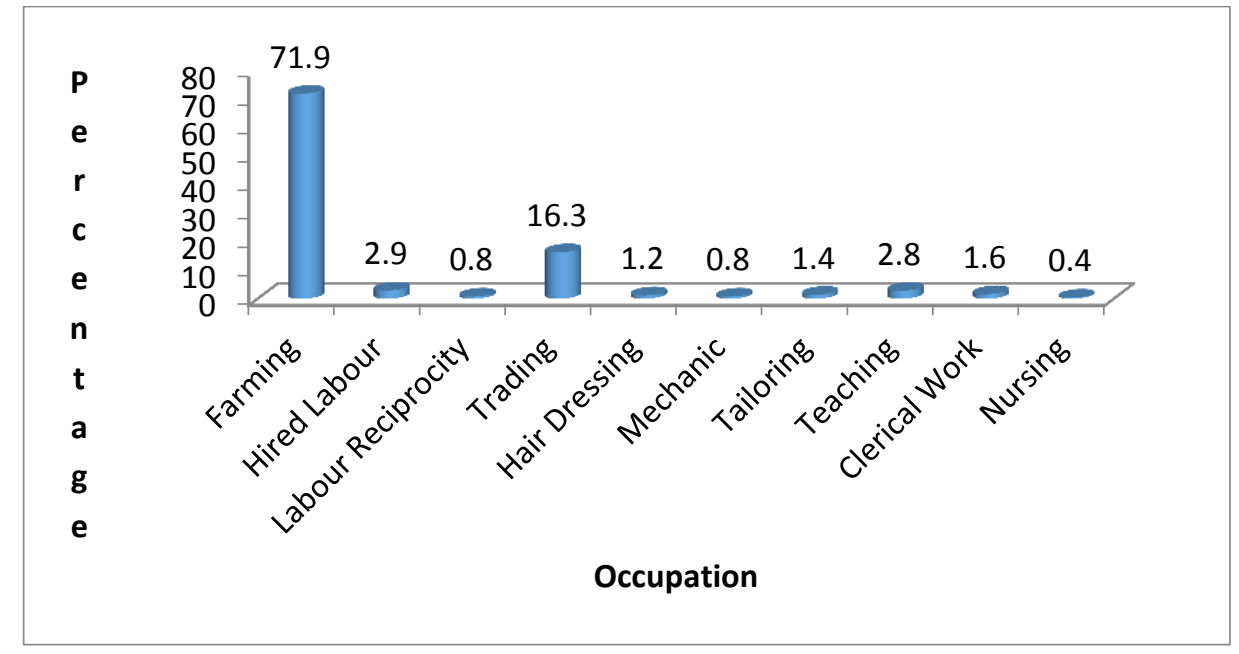

Fig I: Occupational Distribution of Respondents

Source: Authors' Analysis, 2018

Income range among the study respondents was between N50,000 and N600,000 per annum. At an exchange rate of N375 to the United States' Dollar, this translates to between $\$ 133.3$ and $\$ 1,600$ per annum. Income in the study was conceptualized as all forms of earnings from the occupation of the respondents and other earnings from assets owned by the respondents. The latter included rent from buildings, lands and services offered. Owing to the wide disparity of both income extremes, an income quintile was constructed for a proper understanding of the wealth distribution among the rural households of the study area. The quintiles were ranked poorest, poorer, middle, richer and richest. The poorest quintile had respondents earning less than N200,000 per annum while the richest quintile had respondents 
earning between $N 500,000$ and $N 600,000$. The resulting gradation showed that $27.7 \%$ of the respondents belonged in the poorest quintile, $15.3 \%$ in the poorer quintile, $17.0 \%$ in the middle, $20.5 \%$ in the richer quintile and $19.6 \%$ in the richest quintile.

\section{Socioeconomic status and coping strategies}

Major health shocks identified from the analysis of the questionnaire were regular hospitalization and treatment for malaria, typhoid and other febrile illnesses as well occasional bouts of diarrhea, cholera, domestic accidents and work injury. In none of these cases do the households spend less than N3,000 (\$8) per episode per household member. On an annual basis, $67.2 \%$ of the households recorded more than 10 episodes. These episodes were either repeated for some members of the households or just one-off for a member in the same household. To cope with these shocks amidst other household expenses, the households borrowed money from friends, associates and cooperative societies $(47.7 \%)$, sold valuable assets (43.9\%), diverted funds meant for other household activities (2.0\%), and reduced household budget for basic items (6.5\%). The relationship between these coping strategies and the socioeconomic status of the households were analyzed.

As illustrated in Table I, there were occupational, income and educational variations to the choice of coping methods in the sampled households. For instance, $33.3 \%$ of the respondents who borrowed to cope with health shocks were farmers. Farmers also constituted $33.6 \%$ of the respondents who sold their valuable assets to afford out of pocket expenses related to health shocks in the study area. Fewer farmers diverted funds $(0.67 \%)$ or reduced family budgets $(4.47 \%)$ to accommodate the health shocks. Traders ranked second after farmers in borrowing (7.8\%), selling of assets (6.0\%) and cutting down on household expenditure (1.3\%). The highest numbers of respondents who diverted other funds to cope with health shocks however were traders. Teachers, tailors and hairdressers borrowed more than they sold assets, diverted funds or reduced the expenditure of their households whereas mechanics did not borrow but indulged more in sale of assets. Hired labour borrowed and sold off assets but had no funds to divert and did not cut down on their household expenditure.

The poorest of the respondents indulged most in borrowing and selling of assets to cope with health shocks. About 12\% of those who borrowed were respondents in the poorest quintile. Those in the quintile also constituted $14 \%$ of respondents who sold off valuables. Respondents in the middle income, richer and richest quintiles were equally represented ( $9.62 \%$ apiece) in borrowing to cope with health shocks. The richer and richest quintiles ranked second and third respectively in disposing off valuable assets to offset out of pocket expenditure related to health shocks in the study communities. The richest quintile however had the highest representation in diversion of funds and cutting down on household expenditure. The respondents in the poorest and poorer quintiles jointly ranked second (I.34\%) in cutting down household expenses.

Table I: Percentage distribution of respondents' coping strategies by socioeconomic characteristics

\begin{tabular}{|l|c|c|c|c|}
\hline $\begin{array}{l}\text { Socioeconomic } \\
\text { Characteristics }\end{array}$ & \multicolumn{2}{|l|}{ Coping Strategies } \\
\hline Occupation & $\begin{array}{l}\text { Borrowed } \\
(\%)\end{array}$ & Sale of Assets (\%) & Diversion (\%) & $\begin{array}{l}\text { Reduce } \\
\text { Expenditure (\%) }\end{array}$ \\
\hline Farming & 33.33 & 33.56 & 0.67 & 4.47 \\
\hline Hired labour & 1.57 & 1.57 & 0.00 & 0.00 \\
\hline Labour reciprocity & 0.67 & 0.00 & 0.00 & 0.00 \\
\hline Trading & 7.83 & 6.04 & 0.89 & 1.34 \\
\hline Hair dressing & 0.89 & 0.00 & 0.22 & 0.00 \\
\hline Mechanic & 0.00 & 0.89 & 0.00 & 0.00 \\
\hline Tailoring & 1.12 & 0.22 & 0.00 & 0.00 \\
\hline Teaching & 1.34 & 0.67 & 0.22 & 0.45 \\
\hline Clerical work & 0.67 & 0.67 & 0.00 & 0.22 \\
\hline Nursing & 0.22 & 0.22 & 0.00 & 0.00 \\
\hline Income Quintile & & & & 1.34 \\
\hline Poorest & 12.08 & 13.87 & 0.22 & 1.34 \\
\hline Poorer & 6.71 & 6.71 & 0.45 & 0.67 \\
\hline Middle & 9.62 & 6.49 & 0.22 & 0.89 \\
\hline Richer & 9.62 & 9.62 & 0.22 & 2.24 \\
\hline Richest & 9.62 & 7.16 & 0.89 & \\
\hline Education & & & & \\
\hline
\end{tabular}




\begin{tabular}{|l|l|l|l|l|}
\hline Primary education & 13.12 & 11.33 & 0.44 & 0.00 \\
\hline Secondary education & 5.02 & 3.27 & 0.21 & 0.21 \\
\hline Teacher's training & 4.64 & 1.31 & 0.00 & 0.41 \\
\hline Professional school & 7.18 & 0.00 & 0.28 & 0.67 \\
\hline University degree & 10.22 & 0.22 & 2.46 & 1.78 \\
\hline No formal education & 18.27 & 15.47 & 0.98 & 0.63 \\
\hline Others & 0.63 & 0.44 & 0.31 & 0.49 \\
\hline
\end{tabular}

Source: Authors' Computation, 2018

The analysis of the influence of education level of household heads on the coping strategy shows that households where the heads had no formal education constituted the majority in borrowing to cope with health shocks (18.3\%). They also had the highest proportion among households that sold off valuable assets (15.5\%). They were followed closely by households where primary education was the highest qualification of the household heads in the adoption of borrowing and selling of assets as coping strategies with $13.1 \%$ and $11.3 \%$ respectively. While respondents with university degrees ranked third in borrowing, they constituted the majority in diverting funds meant for other household activities to coping with health shocks $(2.5 \%)$ and in reducing household budget for out of pocket expenditure. None of the respondents with primary education reduced household expenditure as a coping mechanism in the study area. A Chi Square statistical test was applied to test the relationships between the socioeconomic variables and coping mechanisms adopted in the households. The results showed that occupation ( $X$ $=547.95, \mathrm{P}<0.005)$, Income $(X=132.57, \mathrm{P}<$ $0.005)$ and Educational attainment of the household heads $(X=326.8 \mathrm{I}, \mathrm{P}<0.005)$ were significantly related to the coping strategies employed in the households.

To further determine the exact relationship between the socioeconomic characteristics and the choice of coping strategies, both set of data were subjected to a multiple regression analysis with the socioeconomic characteristics constituting the independent variables. The results indicate that the predictors accounted for $26.5 \%$ of the variations in coping strategies employed in the study area. The relationship was also statistically significant $(R 2=$ $0.265, \mathrm{P}<0.00 \mathrm{I})$. The partial correlation coefficients of each of the independent variables with the choice of coping strategies show that while occupation $(r=$ $0.397, P<0.0 I)$ and income $(r=0.217, P<0.0 I)$ were positively correlated, education $(r=-0.068, P$ $>0.05)$ was negatively correlated. The association was not statistically significant however. What the results imply is that respondents who were engaged in lower levels of occupation like farming, hired labour and labour reciprocity adopted borrowing and sales of assets as coping strategies more than their 4771 counterparts who were engaged in semi-skilled and skilled occupation like teaching and nursing. The same position is also reflected with the income quintile where poorer respondents borrowed more than divert funds meant for other household expenses.

\section{Discussion of findings}

Borrowing and selling of assets were the dominant coping strategies adopted in the study area. This is as established in the literature (Kazianga and Udry, 2004; McPeak, 2004; Hoddinott, 2006; Goudge et al., 2009; Bonfrer and Gustafsson-Wright, 2017; World Bank, 20|8). Since no health insurance is provided for the poor in rural areas of Nigeria as observed by Onwujekwe et al (20l0), the poorer and the poorest quintiles in this study were found to have adopted borrowing and selling of both productive and unproductive assets as the major coping strategies as also found by Tahsina et al., (2018). Selling of productive asset (Sauerborn et al 1996) which could have been used for future production is an indication that the strategy impacts negatively on the economy of the household (Akazili, 20I0), and may likely lead such households deeper into poverty (World Bank, 2014; Damme et al, 2004). Diversion of funds and cutting down on household expenditures were also adopted as coping strategies in the study area. The World Bank also documents these as household health shocks coping strategies (World Bank, 20l4). What these suggest is that disposable income in the rural areas are either non-existent or very poor and as such, handling out of pocket payments in the rural areas to cope with health shocks is as hard as making a living itself. When this is put in context of the income profile of the rural households, health shocks in rural Nigeria is largely associated with catastrophic payments.

The result also indicates that about $72 \%$ of the rural household heads were farmers. It further indicates that these farmers constituted the majority of those who borrowed or sold assets to finance health related out of pocket expenses. The result corroborates findings by Tahsina et al (20I8). Studies have however found that poor rural households who depend on farming as a mean of livelihood are synonymous with low productivity and hence low http://aps.journals.ac.za 
income (Tirivayi, Knowles and Davis, 20/3). By implication, the bulk of the rural population is poor, characterized by low productivity and largely unable to afford cost of healthcare without borrowing or selling their assets. It is also responsible for why the households quickly resort to seeking financial assistance from other households in the presence of any slightest shock. This has also been found to have negative implications for the donor households as well (Grimm, 2010; Tongruksawattana and Schmidt, 2010). As shown in the study, all the occupational types, except the mechanics, borrowed to support payments for healthcare. It can be said therefore that the option of borrowing seems to be more attractive and probably more convenient across all occupation groups as a first coping strategy.

According to Grossman (1972), age, education and income level are the most influential variables in individual's behaviour toward health and healthcare expenditure. More recently, Arani et al (2017) observed that education affects healthcare expenditure. Educational levels of household heads in this study indicate that level of education of household heads played a very significant role in the choice of coping strategies. It was found that household heads with no formal education (48.3\%) and who didn't have more than primary education (35.4\%) constituted the majority among the household heads. They were also the majority in the adoption of borrowing and selling of assets as coping strategies. By inference, lack of education has implications for the kind of occupation the individual can engage in, and by extension, his income. Most of the household heads without formal education engaged in farming, thus reinforcing the farmingincome-coping strategy cycle of poor households. All the income quintiles in the study borrowed and sold assets. The quintiles may have conceived the true wealth of the rural households but a basic comparison to illuminate this will suffice; more than $40 \%$ of the population lived on less than $\$ 2$ a day! This portends that income is generally poor and health shocks eat deep into this and further impoverishes the rural households. The role of income in accessing quality healthcare and coping with health shocks is well documented (Leonard et al, 2017; Arani et al, 2017; Pradhan and Mukherjee, 2016; Leive \& Xu, 2008).

\section{Conclusion}

Health shocks are idiosyncratic shocks and are a part of individual and households lives. Coping with them however should not be an entirely private affair. Sadly, this is the norm in most low and middle income countries in the absence of national health insurance for the population. This study investigated how households in rural Nigeria cope with these shocks and the influence of socioeconomic characteristics of households on the coping strategies they employ. While borrowing, selling of valuable assets, diversion of funds meant for other household activities and cutting down on household expenditure were the major strategies observed, educational level of household heads, their occupation and income were found to influence these strategies. Underlying the different strategies and their determinants, however, is the lack of institutional support to cushion the effects of catastrophic out of pocket healthcare spending in the households. Having a rural healthcare policy and mainstreaming the informal sector, where the bulk of the rural poor eke a living, into the national health insurance scheme will ameliorate health shocks among the rural poor

\section{References}

Abegunde, D. \& Stanciole, A. (2008). The economic impact of chronic diseases: How do households respond to shocks? Evidence from Russia. Social Science and Medicine, 6(I I):2296 -307.

Adewoyin, Y., Chukwu, N.A. and Sanni, L.M. (20I8). Ghana Journal of Geography Vol. 10(2), 2018 pages $96-111$

Akazili J. (20I0). Equity in Health Care Financing in Ghana. Cape Town (SA): University of Cape Town

Akpomuvie, O.B. (20I0). Poverty, Access to Health Care Services and Human Capital Development in Nigeria. African Research Review Vol. 4(3a): 4I55.

Almeida, A.P, Nunes, P.B., Duro, S.M.S. and Facchini, L.A. (2017). Socioeconomic Determinants of Access to Health Services among Older Adults: a Systematic Review. Rev Saude Publica. 2017; 5l:50.

Arani, A.A., Mardantabar, H., Agheli, L.A. and Ghahreman Abdoli (2017). Analysis of Rural

Households' Behavior in Case of Healthcare Expenditure Considering Income Deciles (Iran: 2009-2014). International Journal of Medical Research \& Health Sciences, 2017, 6(I): 15-20

Asfaw A, Braun J.V. (2004). Is consumption insured against illness? Evidence on vulnerability of households to health shocks in rural Ethiopia. Economic Development and Cultural Change 53 (I): II5- 129

Beegle, K. , Joachim, De Weerdt J., \& Stefan Dercon S. (2008). Adult Mortality and Consumption Growth in the Age of HIV/AIDS. Economic Development and

Cultural Change, 56(2), 299-326.

Bonfrer I \& Gustafsson-Wright E (2017). Health shocks, coping strategies and foregone healthcare 
among agricultural households in Kenya. An International Journal for Research, Policy and Practice https://doi.org/I0.1080/I744/692.2015.1 I 30847

Clarke, D. and Dercon, S. (2009). Insurance, Credit and Safety Nets for the Poor in a World of Risk. DESA Working Paper No. 8I ST/ESA/2009/DWP/8I.

Cohen, L., Manion, L. and Morrison, K. (2007). Research Methods in Education, Sixth Edition. London; Routeledge.

Damme, W. V., Leemput, L. V., Por, I., Hardeman, W., \& Meessen, B. (2004). Out-of-pocket health expenditure and debt in poor households: Evidence from Cambodia. Tropical Medicine \& International Health, 9(2), 273-280. doi:|0.1046/j. I365-3|56.2003.0I | 94.x

Dercon, S. (2002). Income risk, coping strategies, and safety nets. World Bank Research Observer 17, $|4|-166$.

Dercon, S. (2005). Risk vulnerability and poverty in Africa. Journal of African Economics, I4(4), 483488

Dercon S and Krishnan P. (2000). In sickness and in health: risk sharing within households in rural Ethiopia. Journal of Political Economy, 108: 688727 doi: 10.1086/316098

Ephraim-Emmanuel, B.C., Adigwe, A., Oyeghe, R. and Ogaji, D.S (20I8). Quality of Health Care in Nigeria: Myth or Reality. International Journal of Research in Medical Sciences 6(9):2875-288।

European Report on Development. (2010). Social protection for inclusive development. Brussels: European Communities.

Falkingham J. (2004). Poverty, out-of-pocket payments and access to health care: Evidence from Tajikistan. Social Science \& Medicine , 58(2), 247-258.

Flores, G., Krishnakumar, J., O'Donnell, O., \& van Doorslaer, E. (2008). Coping with health-care costs: Implications for the measurement of catastrophic expenditures and poverty. Health Economics, $\quad 17(12)$,

|393-|4|2. doi: $10.1002 /$ hec. 1338

Goudge J , Russel S , Gilson L., (2009) . Illness-related impoverishment in rural South Africa: why does social protection work for some households but not for others? Journal of International Development, 2I: 23I - 25I.

Grimm, M. (20/0). Mortality shocks and survivors' consumption growth. Oxford Bulletin of Economics and Statistics, 72(2), |46-|7|. doi: I 0. I I I I/j. I 468-0084.2009.00566.x

Grimm, M., Hartwig, R., \& Lay, J. (20I I). Investment decisions of small entrepreneurs in a context of strong sharing norms. Conference University of Twente.

Grossman, M. (1972). On the concept of health capital and the demand for health. Journal Of Political Economy, 80(2) 223-55.

Higgins-Steel, A., Noordam, C., Crawford, J. and Fotso, J. (20/5). Improving care-seeking for facility-based health services in a rural, resourcelimited setting: Effects and potential of an mHealth project. African Population Studies, 29 (I): 166382

Hoddinott, J.(2006). Shocks and their consequences across and within households in rural Zimbabwe. Journal of development studies, 64(3), 3 I I-335

Islam, A. Maitra, P. (20|2). Health shocks and consumption smoothing in rural households: Does microcredit have a role to play? Journal of Development Economics, 97 (2): 232 - 243.

Jalan, J. \& Ravallion M. (1999). Are the Poor Less Well Insured? Evidence on Vulnerability to Income Risk in Rural China. Journal of Development Economics, 58,6I-8I.

Kazianga, H. \& Udry C. (2004). Consumption smoothing? Livestock, insurance and drought in rural Burkina Faso. Centre discussion Paper, 898, Yale University

Kenjiro, Y. (2005). Why illness causes more serious economic damage than crop failure in rural Cambodia. Development and Change, 36(4), 759783. doi: |0.|I|||/j.00|2-I55X.2005.00433.x

Lee, W., Jiang, L., Phillips, C.D. and Ohsfeldt, R.L. (20|4). Rural-Urban Differences in Health Care Expenditures: Empirical Data from US Households. Advances in Public Health Volume 2014, Article ID 435780, 8 pages http://dx.doi.org//0.1 |55/20|4/435780

Leive, A., \& Xu, K. (2008). Coping with out-ofpocket health payments: Empirical evidence from I5 African countries. Bulletin of the World Health Organization, 86(I I), 849-856.

Leonard, T., Hughes, A.E. and Pruitt, S.L. (2017). Understanding How Low-Socioeconomic Status Households Cope with Health Shocks: An Analysis of Multisector Linked Data. The Annals of the American Academy, AAPSS, 669, January 2017; 125-I45

Linnemayr, S. (2010). Consumption Smoothing and HIV/AIDS: The Case of Two Communities in South Africa.. Economic Development and Cultural Change, 58(3), 475-506. doi: 10.1086/650420

McPeack, J. (2004). Constraining income shocks with asset shocks: Livestock sales in northern Kenya. Oxford Economic Papers, 56, 263-284

Nguyen, K. T., Hai Khuat, O. T., Ma, S., Pham, D. C., Hong Khuat, G. T., \& Ruger, J. P. (20I2). Coping 
with health care expenses among poor households: Evidence from a rural commune in Vietnam. Social Science \& Medicine, 74(5), 724 733. doi: I0.1016/j.socscimed.20II. 10.027

Nguyen T.N.N., Mangyo E. (2010). Vulnerability of households to health shocks: An Indonesian study. Bulletin of Indonesian Economic Studies, 46 (2): $213-235$

Onwujekwe O. , Hanson K, Uzochukwu B , Ichoku H. , Ike E ,Onwughalu B , (2010) . Are malaria treatment expenditures catastrophic to different socio-economic and geographic groups and how do they cope with payment? A study in southeast Nigeria . Trop Med Int Health, 15: 18 - 25.

Pradhan, K.C. and Mukherjee, S. (2016). Covariate and Idiosyncratic Shocks and Coping Strategies for Poor and Non-Poor Rural Households in India. Working Paper 139/2016, Madras School of Economics.

Quintussi, M., Van de Poel, E., Panda, P. and Rutten, F. (20I5). Economic consequences of ill-health for households in northern rural India. BMC Health Services Research (2015) 15:179

Rahman, M.M., Gilmour, S. Saito E. Sultana , P. \& Shibuya K. (20/3). Self-reported illness and household strategies for coping with healthcare payments in Bangladesh. Bulletin of the World Health Organization 91, 449-458. doi:.org/I0.247I/BLT.12.115428

Rugalema G. (2000). Coping or struggling? A journey into the impact of HIV/AIDS in Southern Africa. Rev Afr Political Economy.;86:537-545.

Russell S. (2004). The economic burden of illness for households in developing countries: A review of studies focusing on malaria, tuberculosis, and human immunodeficiency virus/acquired immunodeficiency syndrome. Am J Trop Med Hyg., $\quad$ 7I(2 Suppl), I47-I55. doi:I0.4269/ajtmh..7I.147

Russell S. (2005). Illuminating cases: understanding the economic burden of illness through case study household research. Health policy and planning, 20(5):277-289. https://doi.org//0.109 3/

Russell, S., \& Gilson, L. (2006). Are health services protecting the livelihoods of the urban poor in Sri Lanka? Findings from two low-income areas of Colombo. Social Science \& Medicine, 63(7), |732-1744. doi: I0.1016/j.socscimed.2006.04.017

Sauerborne N. A , Hien, M \& Diesfield J. (1996). Seasonal variations of household costs of illness in
Burkina Faso. Social Science \& Medicine 43: 28I 290.

Sparrow, R., Van de Poel, E., Hadiwidjaja, G., Yumna, A., Warda, N., \& Suryahadi, A. (20I4). Coping with the economic consequences of ill health in Indonesia. Health Economics, 23(16), 719-728. doi: I0. 1002/hec.2945

Tahsina, T., Ali, N. B., Siddique, M. A. B., Ahmed, S., Rahman, M., Islam, S. \& Arifeen, S. E. (2018). Determinants of hardship financing in coping with out of pocket payment for care seeking of under five children in selected rural areas of Bangladesh. PLOS ONE, 13(5), e0196237. doi:10.137|/journal.pone.0196237

Tirivayi, N., Knowles, M., \& Davis, B. (2013). The interaction between social protection and agriculture. Rome: Food and agriculture organization of the United Nations.

Tongruksawattana, S., Waibel H. \& Schmidt, E. (20I0). Shocks and Coping Actions of Rural Households: Empirical Evidence from Northeast Thailand Paper prepared for the CPRC International Conference 20 I0: Ten Years of War Against Poverty hosted by the Brooks World Poverty Institute at the University of Manchester 8-10 September 2010

United Nations Development Programme (201I). Definition and Types of Shocks and Coping Strategies to be Monitored. Technical Workshop on Monitoring Household Coping Strategies during Complex Crises. Sommerset Millennium Hotel, March 2I, 20I I

Vesel, L., Hipgrave, D., Dowden, J. and Kariuki, W. (20I5) Application of mHealth to improve service delivery and health outcomes: Opportunities and challenges. African Population Studies, 29(I): 1683-98

Wilkes A, Hao Y, Bloom G, Xingyuan G. (1997). Coping with the costs of severe illness in rural China, IDS working paper 58 . China

WHO (20I0). The World Health Report 2010: Health Systems Financing: The Path to Universal Coverage. World Health Organization, Geneva.

World Bank. (20I4). World Development Report 2014: Risk and opportunity - Managing risk for development. Washington, DC: World Bank

Xu, K., Evans, D. B. \& Kawabata K. (2003). Household catastrophic health expenditure: A multi-country analysis. Lancet 362, III - II7. 